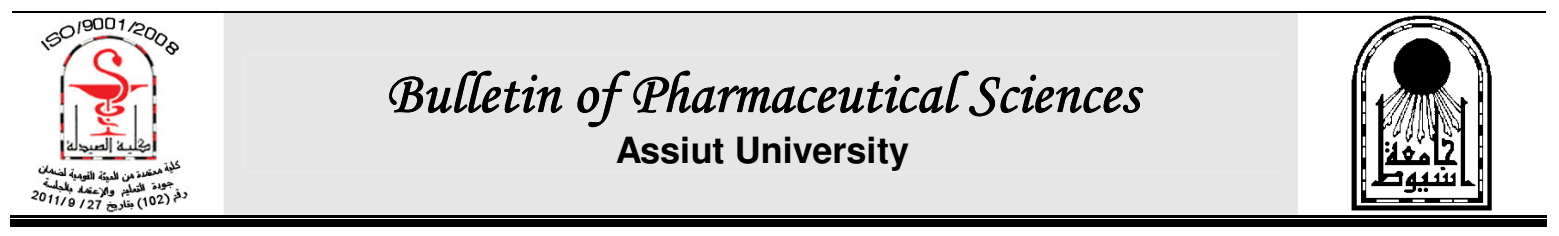

\title{
HISTAMINE IS A HELPFUL NOVEL SEROLOGICAL BIOMARKER FOR EXPERIMENTAL HEPATOCELLULAR CARCINOMA
}

\author{
N. M. Abdel-Hamid ${ }^{1}$, Ahmed A. Abdel-ghany ${ }^{2}$ and Dalia E. Shehata* \\ ${ }^{1}$ Department of Biochemistry, Faculty of Pharmacy, Kafrelsheikh University \\ ${ }^{2}$ Department of Biochemistry, Faculty of Pharmacy, Al-Azhar University, Assiut Branch \\ ${ }^{3}$ Department of Biochemistry, Faculty of Pharmacy, Minia University
}

\begin{abstract}
Aim of the study: Like other cancers, HCC progression is highly affected by angiogenesis and apoptosis. The present study aims to assess the potential role of the endogenous regulators of angiogenesis and apoptosis like neurotransmitters, as possible hepatocellular carcinoma (HCC) biomarkers.

Materials and methods: Five groups of rats were used in this study: a control healthy group(I) and another four intoxicated groups used for induction of HCC with a single dose of diethylnitrosamine (DENA $200 \mathrm{mg} / \mathrm{kg}$, single I.P. dose), (II, III, IV, and V). Groups II, III, IV, and $V$ were sacrificed following 8,16,24, and 32 weeks of the DENA injection respectively. Level of histamine serum samples was estimated using high performance liquid chromatography technique coupled with Diode array detector (HPLC-DAD). In addition, AFP was measured using ELISA technique.

Results: Development of HCC was confirmed by histopathological studies. The results exhibited prominent increase in serum histamine level during early and moderate stages of HCC development (group II, III, and IV) in comparison to the control, then histamine serum level declined to the normal level during last stage of HCC development (group V).

Conclusion: Histamine can be used in combination of AFP as a biomarker for detection of early stages of HCC where AFP alone has a limited detection value.
\end{abstract}

\section{INTRODUCTION}

Hepatocellular carcinoma (HCC) is the third cause of cancer-related death and the fifth most common tumor worldwide ${ }^{1}$. The incidence of HCC varies widely throughout the world, with rising incidence in Egypt $^{2}$. In Egypt, the highest prevalence of hepatitis $\mathrm{C}$ virus $(\mathrm{HCV})$ resulted in growing incidence of $\mathrm{HCC}^{3 \& 4}$, which is nearly doubled over the last decade $^{5-7}$. According to results of National Cancer Registry Program (NCRP) ${ }^{8}$. HCC incidence rate occupied the top ranked cancer among Egyptian males and the second top rank among Egyptian females after breast cancer. The silent growth of HCC may delay the diagnosis of this disease for as long as 3 years from the time of development ${ }^{9}$. Early detection of HCC is the most critical step in the management process, so patients with risk factors for HCC should undergo frequent periodical laboratory investigation every 6 months to predict early development ${ }^{10}$. The diagnosis of HCC without pathologic confirmation can be achieved by the assessment of serum alpha-fetoprotein (AFP) level. Since its discovery in the serum of HCC patients in $1963^{11}$. AFP has been regarded as the most useful serum protein for HCC patients $^{12-14}$. However, we still need to improve the early diagnosis of HCC because only $44 \%$ of the patients are diagnosed at a localized disease stage, and only $30 \%$ of HCC patients at the time of diagnosis are candidates for potentially curative treatments ${ }^{15}$. Thus, the discovery of an effective, reliable tool for early diagnosis of HCC to increase the number of patients who are suitable for curative treatment

Received in 8/12/2015 \& Accepted in 2/2/2016

*Corresponding author: Dalia E Shehata, E-mail: kh_th_pharmacist@yahoo.com 
will play a pivotal role in improving $\mathrm{HCC}$ patients' prognosis.

Neurotransmitters act as powerful upstream regulators that orchestrate numerous cell and tissue functions, by releasing angiogenesis factors, proinflammatory cytokines, growth factors, arachidonic acid, metastasis factors, and local neurotransmitters from cancer cells and their microenvironment. Moreover, they modulate angiogenesis, proliferation, apoptosis, and metastasis of cancer directly by intracellular signaling downstream of neurotransmitter receptors ${ }^{16}$.

Neurotransmitter histamine is a biogenic amine that is released throughout the entire body of an organism ${ }^{17-21}$, with high concentration in the lymph nodes, stomach, and thymus, the lowest concentrations of histamine are found in the liver, brain, intestines, and lung $^{22}$. Histamine is an important chemical mediator that regulates different pathophysiological functions such as cellular invasion, migration, angiogenesis, differentiation, apoptosis, and different immune responses ${ }^{18}$. There have been numerous studies involving histamine in liver cancers. In a study using hepatocellular carcinoma cell lines, histamine stimulation was found to induce a differential effect by increasing the growth of one line while decreasing the growth of another. Histamineinduced effects were attenuated by inhibition of either $\mathrm{H} 1$ or $\mathrm{H} 2 \mathrm{HRs}^{23}$.

\section{MATERIALS AND METHODS}

Animals: Male Sprague-Dawley albino rats about $250 \mathrm{~g}$ were used in the present experiment. They were purchased from the animal house, Assiut University, Assiut. The animals were housed under standardized environmental conditions, fed with standard diet and left to acclimatize to the environment for one week prior to inclusion in the experiment at $22^{\circ} \mathrm{C} \pm 2^{\circ} \mathrm{C}$ under a $12 / 12 \mathrm{hrs}$ light/dark cycle. All the animal experiments were conducted in accordance with the guide for the care and use of laboratory animals of the National Institutes of Health (NIH publication No. 85-23, revised 1985).

Chemicals: Histamine was obtained from Santa Cruz Technology, Inc, UK (cat no. sc- sc-202650). Diethylnitrosoamine (DENA) (cat. no. N0258-1E), was purchased from Sigma Chemical Company, St Louis, MO, USA. Rat Alpha-Fetoprotein (AFP) ELISA kit was obtained from WKEA MED SUPPLIES CORP, China (code no.WAR-348). Other chemicals were obtained either from Sigma Chemical Company or commercial suppliers, unless otherwise mentioned.

Basic experimental design: Diethylnitrosamine (DENA) was used to induce HCC in rats $^{24 \& 25}$ as follows: Animals were divided randomly into five groups as follows: (I) a control healthy group (injected with saline), (II, III, IV, and V) HCC induced groups (injected with DENA, $200 \mathrm{mg} / \mathrm{kg}$ single intraperitonial dose). Groups II, III, IV, and V were sacrificed following 8,16, 24, and 32 weeks of the DENA injection respectively. Rats were initially anesthetized with 3\% halothane before they were sacrificed to collect blood and livers for experimental analyses. Blood samples were collected on the final day of the experiment after a 12 hrs fast. Blood samples were left for $15 \mathrm{~min}$ for in-vitro coagulation and then centrifuged at $3000 \mathrm{xg}$ for $15 \mathrm{~min}$ for serum collection. Blood samples were collected for histamine and AFP measurements.

Liver specimen preparation: Each liver specimen was dissected into 2 pieces. One piece was fixed and embedded in paraffin block for histopathological examination, whereas the second piece was stored in liquid nitrogen (when needed), homogenized for total protein extraction. Liver specimens were fixed in $10 \%$ neutral buffered formalin for $48 \mathrm{hrs}$ at room temperature. The tissues were then placed in embedding cassettes. To prepare the trimmed liver pieces for embedding in paraffin, specimens were first dehydrated gradually using increasing concentrations of ethanol in order to replace water in liver tissues. The liver tissues were then cleared by infiltrating with xylene. Finally, the specimens were infiltrated with $58-60^{\circ} \mathrm{C}$ liquid paraffin. Histological examination was performed on liver samples, stained with hematoxylin and eosin. 


\section{I- Measurement of serum AFP}

Serum AFP was measured in serum of all animal groups using rat alpha-fetoprotein (AFP) ELISA kit (WKEA MED SUPPLIES company, China).

\section{Principle and procedure of assay}

The kit assay Rat AFP level in the sample, use Purified Rat AFP to coat microtiter plate wells, make solid-phase antibody, then add AFP to wells, Combined AFP antibody which With enzyme labeled, become antibody antigen - enzyme-antibody complex, after washing Completely, Add substrate, substrate becomes blue color At HRP enzyme-catalyzed, reaction is terminated by the addition of a sulphuric acid solution and the color change is measured spectrophotometrically at a wavelength of $450 \mathrm{~nm}$. Procedure was done following insert instructions supplied with the kit. Finally the concentration of AFP in the samples was determined by comparing the O.D. of the samples to the standard curve.

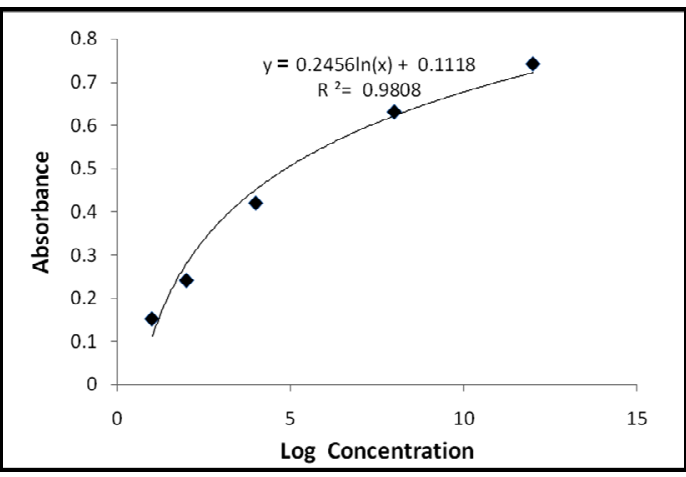

Fig. 1: Standard curve for AFP.

\section{II- Measurement of serum histamine level}

Histamine as one of biogenic amines has been traditionally determined by HPLC using diode array detector ${ }^{26-28}$. In our study we used HPLC-DAD (Agilent Technologies 1200 series, Germany), and separation of histamine occurred on 300SB-C18 $(250 \mathrm{~mm} \times 4.6 \mathrm{~mm}, 5$ $\mu \mathrm{m})$ column (Merck, Darmstadt, Germany). The mobile phase of phosphate buffer $(25 \mathrm{mM}$, $\mathrm{pH} 3$ ) and acetonitrile (5:95) was run isocratic

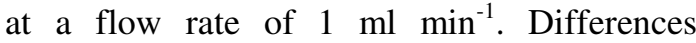
between the control group and the remaining groups were assessed with a 1-way analysis of variance and post hoc Student Neuman-Keuls tests using SPSS.

\section{RESULTS AND DISCUSSION}

\section{Results}

In this study we measured serum AFP as during the development of $\mathrm{HCC}$, as AFP is considered the gold tumor marker for HCC. The results showed an increase in serum AFP level in all experimental groups (Groups II, III, $\mathrm{IV}$, and V) in comparison to control group (Group I), but this increase was significant only during moderate and late stages of $\mathrm{HCC}$ development (Groups IV and $\mathrm{V}$ with $\mathrm{p}$ value $=$ .03 and .01 respectively). Unfortunately there is no significant difference between group IV and $\mathrm{V}$, so the change in AFP level can not reflect the stage of HCC. (Fig. 2, Table 1).

Table 1: Statistics data for serum AFP level in HCC model.

\begin{tabular}{||l|c|c|c|c|c||}
\hline \hline Groups & I & II & III & IV & V \\
\hline $\begin{array}{l}\text { Mean serum AFP } \\
\text { concentration } \\
\text { (ng/ml) }\end{array}$ & .743 & 1.35 & 1.4 & 3.8 & 3.4 \\
\hline Standard Error (SE) & .059 & .228 & .262 & .891 & .989 \\
\hline $\begin{array}{l}\text { Standard Deviation } \\
\text { (SDV) }\end{array}$ & .167 & .646 & .742 & 2.52 & 2.79 \\
\hline
\end{tabular}

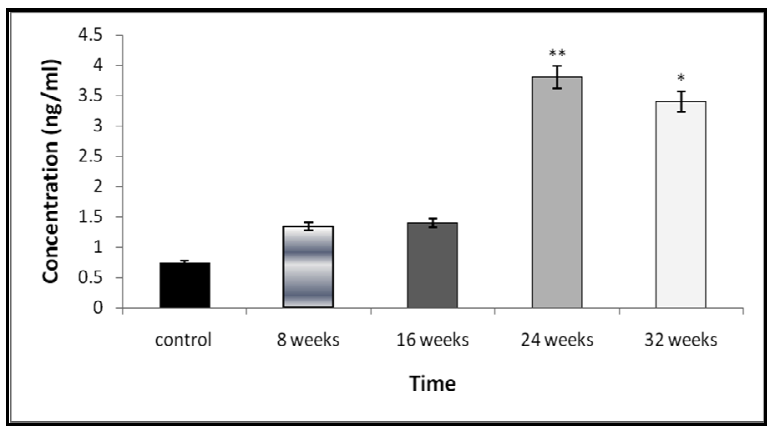

Fig. 2: Serum AFP concentration ( $\mathrm{ng} / \mathrm{ml})$ during different stages of HCC.

Control: group of mice injected with normal saline only. 8, 16, 24 and 32 weeks: the time from DENA injection till sacrificing the animals. SPSS program was used for statistics calculations where: Sign (*) refer to significant difference between each group and control at $\mathrm{p}$ value $\leq .05$. Sign $(* *)$ refer to highly significant difference between each group and control at $p$ value $\leq .01$. Sign (\#) refer to significant difference between any group and its previous group at $\mathrm{p}$ value $\leq .05$. Sign (\#\#) refer to highly significant difference between any group and its previous group at $\mathrm{p}$ value $\leq .01$. 
Histamine is a biogenic amine have been shown to induce a multitude of effects on various cellular pathologies with growing evidence suggests that histamine and the histamine receptors may be involved in tumor growth and/or depletion ${ }^{19 \& 30}$. Our results showed a highly significant increase in serum histamine level than the control during early stages of HCC development (Group II and III with $\mathrm{p}$ value $<.001$ ), while serum histamine level for moderate stage of HCC development (Group IV) showed significant increase ( $p$ value $=.01)$ than the control group and significant decrease $(p$ value $<.001)$ than early stage groups (II and III), finally group V which represents the late stage of HCC development showed return of serum histamine to normal level without any significant change than the control (Fig. 3, Table 2).

Table 2: Statistics data for serum histamine level in HCC model.

\begin{tabular}{||l|c|c|c|c|c||}
\hline \multicolumn{1}{|c|}{ Groups } & I & II & III & IV & V \\
\hline $\begin{array}{l}\text { Mean serum } \\
\text { histamine } \\
\text { concentration( ng/ml) }\end{array}$ & 35.2 & 114.5 & 110.18 & 64.78 & 39.91 \\
\hline Standard Error (SE) & 12.45 & 40.49 & 38.95 & 22.90 & 14.11 \\
\hline $\begin{array}{l}\text { Standard Deviation } \\
\text { (SDV) }\end{array}$ & 3.76 & 12.4 & 15.47 & 17.59 & 14.67 \\
\hline
\end{tabular}

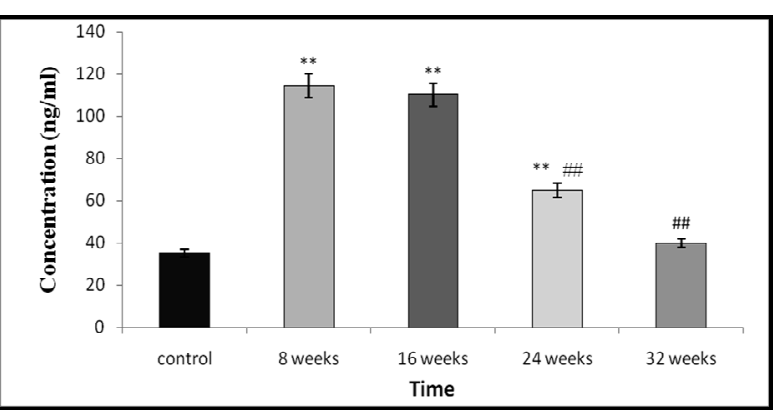

Fig. 3: Serum histamine concentration ( $\mathrm{g} / \mathrm{ml})$ during different stages of HCC development.

Control: group of mice injected with normal saline only. 8, 16, 24 and 32 weeks: the time from DENA injection till sacrificing the animals. -SPSS program was used for statistics calculations where: Sign $(*)$ refer to significant difference between each group and control at $\mathrm{p}$ value $\leq .05$. Sign (**) refer to highly significant difference between each group and control at $\mathrm{p}$ value $\leq .01$. Sign (\#) refer to significant difference between any group and its previous group at $\mathrm{p}$ value $\leq .05$. Sign (\#\#) refer to highly significant difference between any group and its previous group at $\mathrm{p}$ value $\leq .01$.
Histopathological examination of hepatic tissues: A Normal hepatic tissue showed normal cellular shape with no sinusoidal growth pattern, cellular and nuclear pleomorphism, prominent nucleoli, or increased nuclear/cytoplasmic ratio (N/C ratio) as shown in (Fig. 4-A). 8 weeks after adminstration of DENA (in a dose of 200 $\mathrm{mg} / \mathrm{kg}$ body eight I.P.) resulted in increased nuclear/cytoplasm (N/C) ratio with high grade sinusoidal pattern (Fig. 4-B). 16 weeks after adminstration of DENA caused multinuclear giant cell formation with increased mitotic figures (Fig. 4-C). 24 weeks after adminstration of DENA showing multinuclear giant cell formation and increased width of cord cells more than two cells, and poorly differentiated HCC (Fig. 4-D). 32 weeks post DENA injection showing cellular and nuclear polcomorphism, increased width of cord cells more than two cells, with microacinar formation (Fig. 4-E).

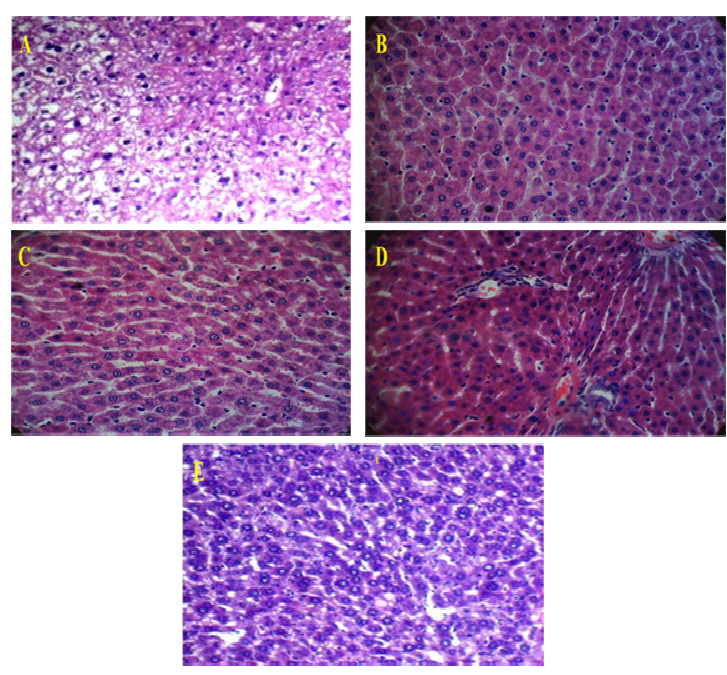

Fig. 4: Histopathological examination of hebatic tissue.

A Normal hepatic tissue sections showing normal cellular architecture with no sinusoidal growth pattern, or increased nuclear/cytoplasmic ratio (H\&E x100). B Hepatic tissue section of group II (8 weeks post DENA injection) showing increased nuclear/ cytoplasm (N/C) ratio with high grade sinusoidal pattern. C group III (16 weeks post DENA injection) showing multinuclear giant cell formation with increased mitotic figures. D group IV (24 weeks post DENA injection) showing poorly differentiated HCC. $\mathbf{E}$ group V (32 weeks post DENA injection) showing cellular and nuclear poleomorphism, increased width of cord cells more than two cells, with microacinar formation. 


\section{Discussion}

Although histamine was proposed since 1960 to have a probable role in carcinogenesis $^{21}$, it still remains under discussion today. Histamine can produce different and, sometimes, contradictory effects on tumor cell growth through activation of its four membrane-specific receptors, $\mathrm{H} 1, \mathrm{H} 2, \mathrm{H} 3$ and H4. Moreover, most of the physiological and pathological actions of histamine have been shown to strictly depend on both its endogenous/ exogenous concentration and the tumor cell type under study. $\mathrm{H} 1$ and $\mathrm{H} 2$ receptors were the first two histamine receptor subtypes described and thus, the most frequently investigated in tumor cells and tissues. Selective activation of the $\mathrm{H} 1$ or $\mathrm{H} 2$ receptor has been shown to produce, respectively, inhibition or stimulation of tumor growth in a dose-dependent manner ${ }^{31832}$.

Our results showed a highly significant increase in serum histamine level than the control during early stages of HCC development (Group II and III), while serum histamine level for moderate stage of HCC development (Group IV) showed significant increase than the control group and significant decrease than early stage groups (II and III), finally group $\mathrm{V}$ which represents the late stage of HCC development showed return of serum histamine level to normal without any significant change than the control. We can explain our results depending on the diverse effects of histamine which were found in many types of cancer, where this diverse effect owed to difference in histamine concentration, for example in induced mammary adenocarcinoma and pancreatic carcinoma, histamine in low concentrations increases tumor cell proliferation whereas higher histamine levels decreases cell proliferation via receptor activation thereby inducing a G0/G1 cell cycle arrest associated with partial stimulation of cell differentiation ${ }^{33 \& 34}$. Histamine can behave as a pro- or an anti-proliferative factor within the same tumor type cells, depending on its concentration and the receptor subtype to which it binds ${ }^{35}$. Similar results have been reported for hepatocellular carcinoma cells ${ }^{23}$. Transformation of the initiated hepatocytes into hepatocellular carcinoma is a multistage complex process, and occurs through various stages which include disease initiation, promotion and progression ${ }^{36}$. Histopathological results for our experiment show slow rate for HCC growth during the first 16 weeks (group II $\&$ III), these two groups also show high serum histamine level, while the rapid cancer growth was in group IV\&V which showed significant decrease in serum histamine level than groups II and III, so high histamine level in group II \&III may be responsible for the tumor growth suppression in these groups, while low histamine level in group IV \&V promotes tumor cell proliferation.

It is known that histamine is induced and readily made available in rapidly growing tissues $^{37}$. Within these tissues, intracellular histamine is released from mast cells ${ }^{38 \& 39}$. Histamine can also be catalyzed from Lhistidine by the enzyme $\mathrm{L}$ histidine decarboxylase (HDC) $)^{40 \& 41}$. So we have two probable reasons for change in serum histamine level, change in HDC level and/ or change in mast cell number.

Accumulated evidence points to a direct relationship between upregulation of HDC activity and growth of several types of human tumors. Over expression of HDC at both the mRNA and protein levels and increased levels of histamine have been shown in melanoma ${ }^{42}$, small cell lung carcinoma ${ }^{43}$, breast carcinoma ${ }^{44}$, endometrial cancer ${ }^{45}$ and colorectal carcinoma $^{46}$. Burtin and et al. measured HDC in patients suffering from primary liver cancer and found that change in histamine level not accompanied by any change in HDC level ${ }^{47}$, so another explanation for change in histamine level during $\mathrm{HCC}$ growth is needed.

Mast Cells where histamine is stored are increased in number in association with many types of malignant tumors ${ }^{48-50}$. HCC tissues with different histological grades showed different numbers of mast cells, with welldifferentiated HCC showing the highest number. They tended to decrease in lessdifferentiated HCC, suggesting a possible role in the early stage of HCC development ${ }^{51}$, so this may be the explanation for the significant increase then the decrease in serum histamine level which we recorded in our work during early and last stages of hepatocellular carcinoma development respectively. 


\section{Conclusion}

Measurement of histamine serum level may have an important diagnostic value for early detection of HCC growth, and more investigation is needed to evaluate the diagnostic efficacy of histamine serum level in screening process of HCC- high risk populations as those with cirrhotic liver due to viral hepatitis or alcoholism.

\section{REFERENCES}

1- D. M. Parkin, et al., "Estimating the world cancer burden: Globocan 2000", International Journal of Cancer, 94 (2), 153-156 (2001).

2- M. C. Yu, et al., "Epidemiology of hepatocellular carcinoma", Journal Canadien de Gastroenterologie, 14 (8), 703-709 (2000).

3- F. Abdel-Aziz, et al., "Hepatitis C virus (HCV) infection in a community in the Nile Delta: Population description and HCV prevalence", Hepatology, 32 (1), 111-115 (2000).

4- M. A. Khattab, et al., "Seroprevalence of hepatitis $\mathrm{C}$ and $\mathrm{B}$ among blood donors in Egypt: Minya Governorate, 2000-2008", American Journal of Infection Control, 38 (8), 640-641 (2010).

5- M. M. Hassan, et al., "The role of hepatitis $\mathrm{C}$ in hepatocellular carcinoma: A case control study among Egyptian patients", Journal of Clinical Gastroenterology,. 33 (2), 123-126 (2001).

6- A. R. El-Zayadi, et al., "Hepatocellular carcinoma in Egypt: A single center study over a decade", WJG, 11 (33), 5193-5198 (2005).

7- L. S. Freedman, et al., "Cancer incidence in four member countries (Cyprus, Egypt, Israel, and Jordan) of the Middle East Cancer Consortium (MECC) compared with US SEER", (2006).

8- A. S. Ibrahim, et al., "Cancer incidence in Egypt: Results of the national populationbased cancer registry program", Journal of Cancer Epidemiology, (2014).

9- Y. Tanaka, et al., "A comparison of the molecular clock of hepatitis $\mathrm{C}$ virus in the United States and Japan predicts that hepatocellular carcinoma incidence in the
United States will increase over the next two decades", Proceedings of the National Academy of Sciences, 99 (24), 15584-15589 (2002).

10- M. Abdel-Hamid, "Priority considerations in early laboratory diagnosis of hepatocellular carcinoma", IJIB, 3 (3), 196-201 (2008).

11- G. Abelev, et al., "Production of embryonal [alpha]-globulin by transplantable mouse hepatomas", Transplantation, 1 (2), 174-180 (1963).

12- N. Nagasue, et al., "Serum alpha-fetoprotein levels after hepatic artery ligation and postoperative chemotherapy, Correlation with clinical status in patients with hepatocellular carcinoma", Cancer, 40 (2), 615-618 (1977).

13- P. Tangkijvanich, et al., "Clinical characteristics and prognosis of hepatocellular carcinoma: Analysis based on serum alpha-fetoprotein levels", Journal of Clinical Gastroenterology, 31 (4), 302-308 (2000).

14- L. Zhou, J. Liu and F. Luo, "Serum tumor markers for detection of hepatocellular carcinoma", WJG, 12 (8), 1175-1181 (2006).

15- J. M. Llovet, et al., "Arterial embolisation or chemoembolisation versus symptomatic treatment in patients with unresectable hepatocellular carcinoma: A randomised controlled trial", The Lancet, 359 (9319), 1734-1739 (2002).

16- H. M. Schuller, "Neurotransmission and cancer: Implications for prevention and therapy", Anti-Cancer Drugs, 19 (7), 655671 (2008).

17- I. J. de Esch, et al., "The histamine H 4 receptor as a new therapeutic target for inflammation", Trends in Pharmacological Sciences, 26 (9), 462469 (2005).

18- G. Coruzzi, M. Adami and C. Pozzoli, "Role of Histamine H4 Receptors in the Gastrointestinal Tract", Front Biosci., (Schol. Ed.), 2012. 4, pp. 226-239.

19- H. Hegyesi, et al., "Retinoic acid enhances histamine content and $\mathrm{H} 1$ receptor expression in human neuroblastoma cell line Paju", Anticancer Research, 24 (3A), 1657-1664 (2004). 
20- S. Hill, et al., "International Union of Pharmacology. XIII. Classification of histamine receptors", Pharmacological Reviews, 49 (3), 253-278 (1997).

21- G. Kahlson and E. Rosengren, "New approaches to the physiology of histamine", Physiol. Rev., 48 (1), 155-196 (1968).

22- A. S. Zimmermann, et al., "Systematic analysis of histamine and Nmethylhistamine concentrations in organs from two common laboratory mouse strains: $\mathrm{C} 57 \mathrm{~B} 1 / 6$ and $\mathrm{Balb} / \mathrm{c}$, Inflammation Research, 60 (12), 11531159 (2011).

23- N. Lampiasi, et al., "Histamine and spontaneously released mast cell granules affect the cell growth of human hepatocellular carcinoma cells", Experimental and Molecular Medicine, 39 (3), 284-294 (2007).

24- S. Bhattacharya and M. Chatterjee, "Protective role of Trianthema portulacastrum against diethylnitrosoamine-induced experimental hepatocarcinogenesis", Cancer Letters, 129 (1), 7-13 (1998).

25- H. C. Pitot, et al., "Biochemical characterisation of stages of hepatocarcinogenesis after a single dose of diethylnitrosamine", Nature, 271 (5644), 456-458 (1978).

26- I. Basozabal, et al., "Rational design and chromatographic evaluation of histamine imprinted polymers optimised for solidphase extraction of wine samples", Journal of Chromatography, A, 1308, 45-51 (2013).

27- B. Bach, et al., "Validation of a method for the analysis of biogenic amines: Histamine instability during wine sample storage", Analytica Chimica Acta, 732, 114-119 (2012).

28- A. Önal, "A review: Current analytical methods for the determination of biogenic amines in foods", Food Chemistry, 103 (4), 1475-1486 (2007).

29- H. Francis, et al., "H3 Histamine Receptor-Mediated Activation of Protein Kinase $\mathrm{C} \alpha$ Inhibits the Growth of Cholangiocarcinoma In-vitro and In-vivo", Molecular Cancer Research, 7 (10), 1704-1713 (2009).
30- V. Medina, et al., "The role of histamine in human mammary carcinogenesis: H3 and $\mathrm{H} 4$ receptors as potential therapeutic targets for breast cancer treatment", Cancer Biology \& Therapy, 7 (1), 28-35 (2008).

31- M. A. Medina, et al., "Histamine, polyamines, and cancer", Biochemical Pharmacology, 57 (12), 1341-1344 (1999).

32- Z. Pós, H. Hegyesi and E. S. Rivera, "Histamine and Cell Proliferation", Histamine: Biology and Medical Aspects, $1^{\text {st }}$ Ed. Budapest: SpringMed Publishing Ltd, 2004, pp. 199-217.

33- E. S. Rivera, et al. "Histamine as an Autocrine Growth Factor: An Unusual Role for a Widespread Mediator", In: Seminars in Cancer Biology, 2000. Elsevier.

34- G. Cricco, et al., "Histamine regulates the MAPK pathway via the $\mathrm{H} 2$ receptor in PANC-1 human cells", Inflammation Research, 53, S65-S66 (2004).

35- F. Cianchi, M. Cristina Vinci and E. Masini, "Histamine in cancer: The dual faces of the coin", Cancer Biology \& Therapy, 7 (1), 36-37 (2008).

36- E. Farber and D. Sarma, "Hepatocarcinogenesis: A dynamic cellular perspective Laboratory investigation", Journal of Technical Methods and Pathology, 56 (1), 4-22 (1987).

37- V. Medina, et al., "Role of Histamine H4 Receptor in Breast Cancer Cell Proliferation", Frontiers in Bioscience (Elite edition), 2010. 3, pp. 1042-1060.

38- D. G. Ebo, et al., "Analyzing histamine release by flow cytometry (HistaFlow): A novel instrument to study the degranulation patterns of basophils", Journal of Immunological Methods, 375 (1), 30-38 (2012).

39- Z. Li, et al., "Expression of non-mast cell histidine decarboxylase in tumorassociated microvessels in human esophageal squamous cell carcinomas", Apmis, 116 (12), 1034-1042 (2008).

40- A. Tanimoto, et al., "Histidine decarboxylase expression in pancreatic endocrine cells and related tumors", Pathology International, 54 (6), 408-412 (2004). 
41- K. Yatsunami, T. Fukui and A. Ichikawa, "Molecular biology of L-histidine decarboxylase", Yakugaku Zasshi: Journal of the Pharmaceutical Society of Japan, 114 (11), 803-822 (1994).

42- H. Hegyesi, et al., "Suppression of melanoma cell proliferation by histidine decarboxylase specific antisense oligonucleotides", Journal of Investigative Dermatology, 117 (1), 151153 (2001).

43- L. Graff, et al., "Expression of histidine decarboxylase and synthesis of histamine by human small cell lung carcinoma", The American Journal of Pathology, 160 (5), 1561-1565 (2002).

44- M. Garcia-Caballero, et al., "Histamine synthesis and content in benign and malignant breast tumours. Its effects on other host tissues", Surgical Oncology,. 3 (3), 167-173 (1994).

45- R. Chanda and A. Ganguly, "Diamineoxidase activity and tissue di-and polyamine contents of human ovarian, cervical and endometrial carcinoma", Cancer Letters, 89 (1), 23-28 (1995).

46- M. Garcia-Caballero, et al., "Increased histidine decarboxylase (HDC) activity in human colorectal cancer: Results of a study on ten patients", Agents and Actions, 23 (3-4), 357-360 (1988).
47- C. Burtin, et al., "Decreased blood histamine levels in patients with solid malignant tumours", British Journal of Cancer, 47 (3), 367 (1983).

48- E. R. Fisher, et al., Tissue mast cells in breast cancer", Breast Cancer Research and Treatment, 5 (3), 285-291 (1985).

49- R. M. Graham and J. Graham, "Mast cells and cancer of the cervix", Surgery, Gynecology \& Obstetrics, 123 (1), 3-9 (1966).

50- E. R. Fisher, et al., "Prognostic significance of eosinophils and mast cells in rectal cancer: Findings from the National Surgical Adjuvant Breast and Bowel Project (protocol R-01)", Human Pathology, 20 (2), 159-163 (1989).

51- M. Cervello, et al., "Correlation between expression of cyclooxygenase- 2 and the presence of inflammatory cells in human primary hepatocellular carcinoma: Possible role in tumor promotion and angiogenesis", World Journal of Gastroenterology, 11 (30), 4638 (2005). 


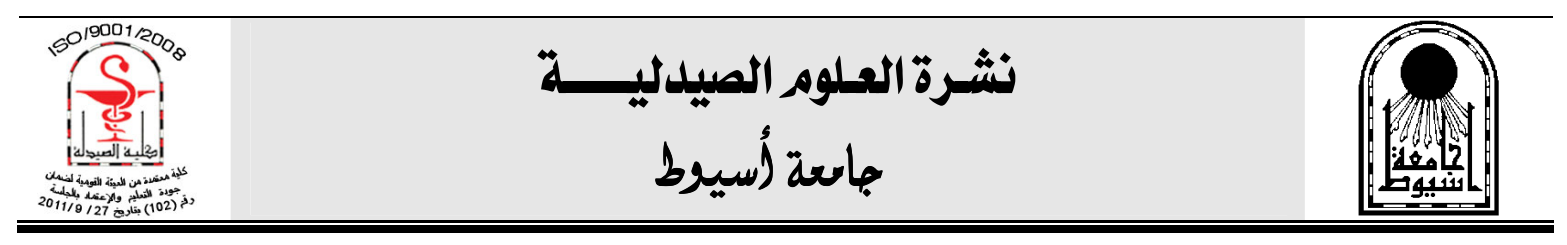

\section{الهستامين كعامل جليد مساعد لتثخيص سرطان الكبد الخلوي معملياً

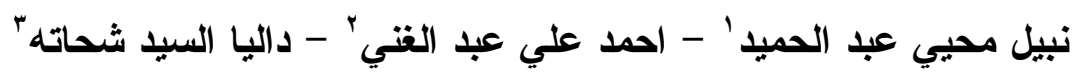

'قسم الكيمياء الحيوية ، كلية الصيدلة ، جامعة المنيا

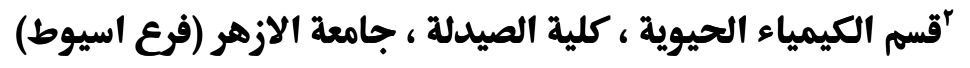

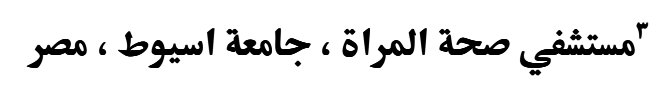

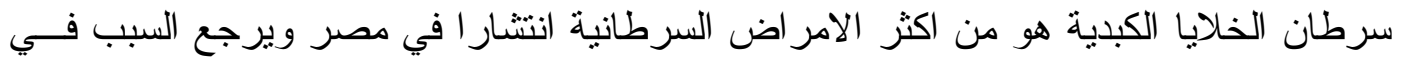

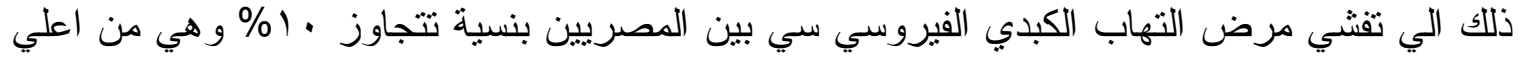

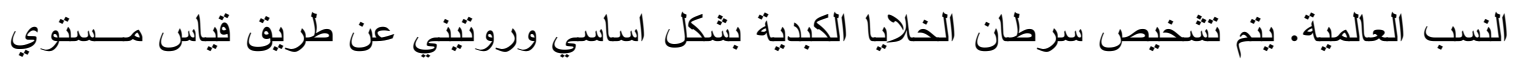

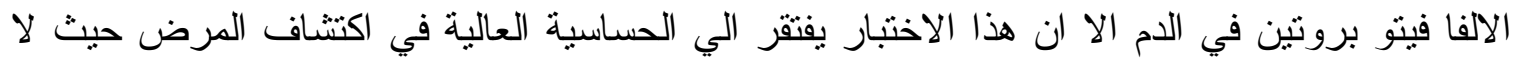

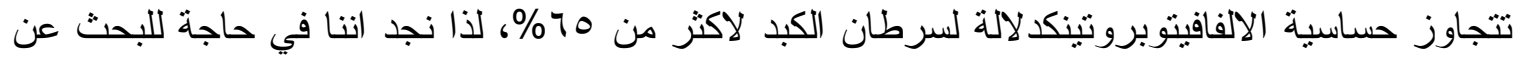

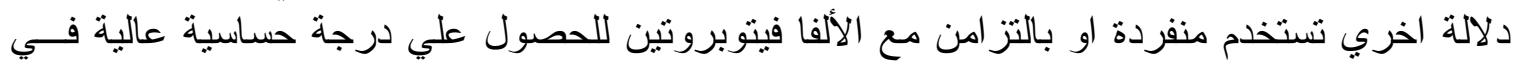

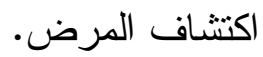

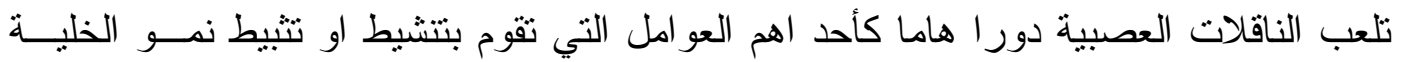

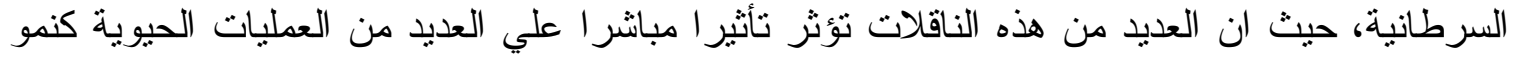

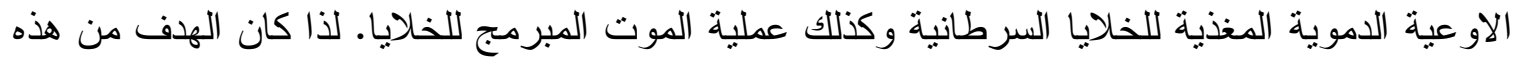

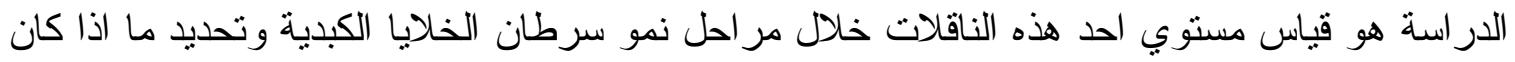

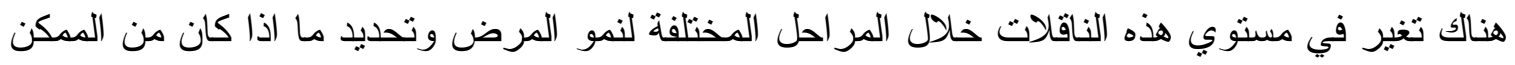

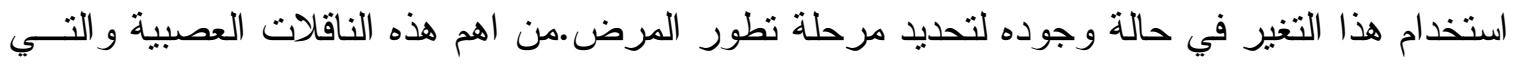

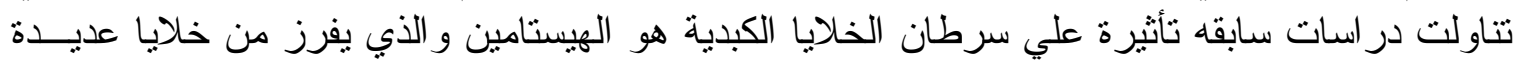

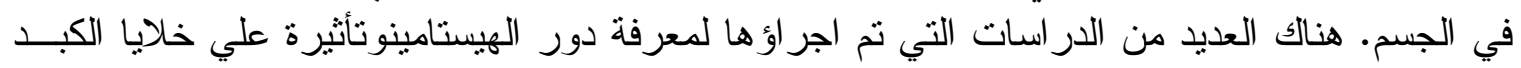

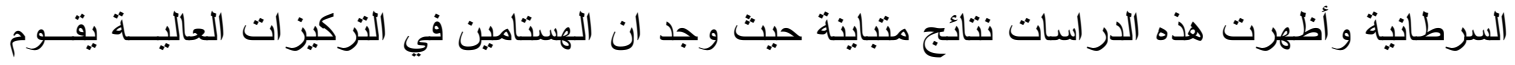

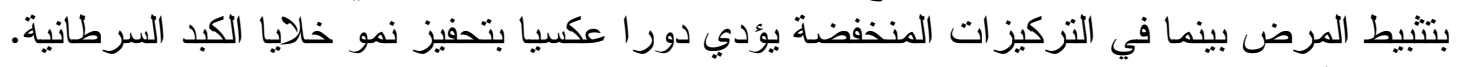

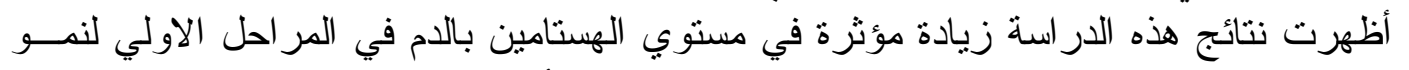

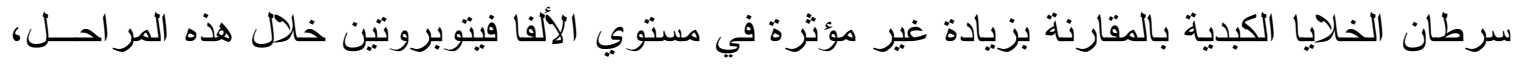

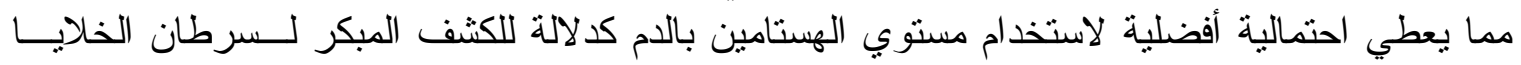
الكبدية. 